\title{
Neuregulin-1 attenuates mortality associated with experimental cerebral malaria
}

\author{
Wesley Solomon ${ }^{1 *+}$, Nana O Wilson ${ }^{1}$, Leonard Anderson ${ }^{2 \dagger}$, Sidney Pitts ${ }^{3+}$, John Patrickson ${ }^{3+}$, Mingli Liu ${ }^{1 \dagger}$, \\ Byron D Ford ${ }^{4 \dagger}$ and Jonathan K Stiles ${ }^{1 *+}$
}

\begin{abstract}
Background: Cerebral Malaria (CM) is a diffuse encephalopathy caused by Plasmodium falciparum infection. Despite availability of antimalarial drugs, CM-associated mortality remains high at approximately $30 \%$ and a subset of survivors develop neurological and cognitive disabilities. While antimalarials are effective at clearing Plasmodium parasites they do little to protect against CM pathophysiology and parasite-induced brain inflammation that leads to seizures, coma and long-term neurological sequelae in CM patients. Thus, there is urgent need to explore therapeutics that can reduce or prevent CM pathogenesis and associated brain inflammation to improve survival. Neuregulin-1 (NRG-1) is a neurotrophic growth factor shown to protect against brain injury associated with acute ischemic stroke (AIS) and neurotoxin exposure. However, this drug has not been tested against CM-associated brain injury. Since CM-associated brain injuries and AIS share similar pathophysiological features, we hypothesized that NRG-1 will reduce or prevent neuroinflammation and brain damage as well as improve survival in mice with late-stage experimental cerebral malaria (ECM).

Methods: We tested the effects of NRG-1 on ECM-associated brain inflammation and mortality in P. berghei ANKA $(\mathrm{PbA})$-infected mice and compared to artemether (ARM) treatment; an antimalarial currently used in various combination therapies against malaria.

Results: Treatment with ARM ( $25 \mathrm{mg} / \mathrm{kg} /$ day) effectively cleared parasites and reduced mortality in PbA-infected mice by $82 \%$. Remarkably, NRG-1 therapy $(1.25 \mathrm{ng} / \mathrm{kg} /$ day) significantly improved survival against ECM by $73 \%$ despite increase in parasite burden within NRG-1-treated mice. Additionally, NRG-1 therapy reduced systemic and brain pro-inflammatory factors TNFalpha, IL-6, IL-1alpha and CXCL10 and enhanced anti-inflammatory factors, IL-5 and IL-13 while decreasing leukocyte accumulation in brain microvessels.
\end{abstract}

Conclusions: This study suggests that NRG-1 attenuates ECM-associated brain inflammation and injuries and may represent a novel supportive therapy for the management of CM.

Keywords: Neuregulin-1 (NRG-1), Pro-inflammatory, Anti-inflammatory, Blood-brain barrier (BBB), Inflammation, Plasmodium berghei ANKA (PbA), Adjunctive therapy, Malaria, Cerebral malaria (CM), Brain injury

\section{Background}

Nearly 300 million persons each year are infected with Plasmodium falciparum (P. falciparum) infection, a subset of whom may develop severe anemia or a diffuse encephalopathy known as cerebral malaria (CM) [1]. CM accounts for 110,000 deaths annually in children and one in four survivors develop neurological complications

\footnotetext{
*Correspondence: wsolomon@msm.edu; jstiles@msm.edu

${ }^{\dagger}$ Equal contributors

'Department of Microbiology, Biochemistry and Immunology, Morehouse School of Medicine, Atlanta, GA, USA

Full list of author information is available at the end of the article
}

(cortical blindness, epilepsy, and monoparesis) and cognitive disability (speech deficits, working memory, and executive function disability) [2-8]. Despite appropriate antimalarial treatment, mortality associated with CM may be as high as $30 \%$ in adults and $20 \%$ in children [7,9-11]. Thus, targeting parasite in acute disease is not sufficient to ameliorate persistent neurological sequelae and mortality associated with CM. Understanding immunopathogenic features such as brain inflammation and injury leading to fatal $\mathrm{CM}$ have led to the identification and development of small molecules or immunotherapeutics 
that may be used to stabilize the blood-brain barrier (BBB) and ameliorate $\mathrm{CM}$-associated brain damage and mortality [12-14]. However, most of these interventions administered as prophylactics to prevent development of neurological signs failed to reverse CM-associated brain injuries or resulted in minimal therapeutic benefit, whereas others were deleterious $[13,14]$. The use of prophylactic strategies may not be clinically relevant as most patients who present to clinics have neurological abnormalities or clinical signs of CM. It is therefore important for new therapeutic strategies to ameliorate complications associated with late stages of $\mathrm{CM}$ to improve clinical outcomes while reducing risk of neurological sequelae in surviving $\mathrm{CM}$ patients. Clinical studies in human CM and murine experimental CM (ECM) indicate an exaggerated activation and dysregulation of host inflammatory processes including brain endothelial activation, and disruption of the $\mathrm{BBB}$ during the pathogenesis of the disease [15-18]. In fact, extensive research has linked strong host proinflammatory response to malaria disease states [19-21] and genetic studies have identified several immune regulatory and effector loci that possess mutations associated with susceptibility and resistance to human severe (cerebral) malaria [22-24]. Efforts underway to identify candidate therapeutics against CM have produced promising candidates including artovastatin, a statin with strong anti-inflammatory effects that effectively attenuates ECM [25-27]. Thus, interventions aimed at modulating the deleterious hyper-inflammatory response to malaria infection while protecting against brain damage will potentially bolster therapeutics against severe malaria.

Neuregulin-1 (NRG-1) is a member of the neuregulin family of growth factors that promotes survival and function of neuronal cells [28-31]. Studies have shown that NRG-1 attenuates tissue damage and immunopathology in animal models of acute brain injury (ABI) such as acute ischemic stroke (AIS), traumatic brain injury (TBI), and nerve agent poisoning [32-37]. There are clear pathophysiological similarities between CM and AIS, including an exaggerated host expression of pro-inflammatory factors that lead to increased vascular endothelial activation with upregulation of adhesion molecules, glial activation, focal inflammation, activation of apoptotic pathways and eventually brain damage and death [38-40]. Exogenous treatment with NRG-1 has been shown to significantly alter or inactivate inflammatory pathways associated with tissue damage during ischemic episodes [36]. Furthermore, NRG-1 reduces brain inflammation via inhibition of immune and oxidative stress mediators involved in the pathogenesis of focal ischemic brain damage [32]. Although NRG-1 has been studied extensively in AIS it has yet to be studied as a potential intervention against cerebral malaria. Using the Plasmodium berghei (P. berghei) ANKA (PbA) model of
ECM, we tested the hypothesis that NRG-1 will reduce or prevent ECM-associated inflammation and improve survival in mice with late stage ECM. We show here that NRG-1 (1.25 ng/kg/day) significantly reduces ECM-associated brain and systemic inflammation and improves survival in mice with late-stage ECM.

\section{Methods}

\section{Infection of mice with $P$. berghei ANKA}

Six- to eight-week-old C57BL/6 J mice (Charles Rivers Laboratories, Wilmington, MA, USA) were housed in groups of four per cage on a $12 \mathrm{hr}$ light $/ 12 \mathrm{hr}$ dark cycle with access to food ad libitum and water. Mice were allowed to acclimatize to their new environment for 3 days before experimentation. All experimental procedures were reviewed and approved by the Morehouse School of Medicine Institutional Animal Care and Use Committee (Permit Number 09-06). Procedures were performed with strict adherence to national regulations on animal care and experimentation with the use of Care of Laboratory Animal Resources (CLAR) guidelines to minimize pain. PbA was obtained from MR4, Manassas, VA, USA (BEI Resources Repository, NIAID, NIH; MR4 number MRA-311, deposited by TF McCutchan). Parasites were propagated in $C 57 B L / 6 J$ mice and a fresh blood sample from a passage mouse was used for each experiment. Experimental groups of mice were infected via intraperitoneal (i.p.) injection of $10^{6} \mathrm{PbA}$-infected red blood cells ( $\mathrm{pRBCs}$ ). Mice were sham-injected with $10^{6}$ non-infected red blood cells (RBCs).

\section{Clinical assessment of ECM}

All animals were checked several times daily for mortality and ECM symptoms. For better estimation of the overall clinical status of mice during infection, simple behavioral tests (transfer arousal, locomotor activity, tail elevation, wire maneuver, contact righting reflex, and righting in arena) adapted from the SmithKline Beecham, Harwell, Imperial College, Royal London Hospital, phenotype assessment (SHIRPA) protocol [41-43] were used. Infected mice display signs of ECM by day 5 or 6 post infection [41]. ECM is defined as the presentation of one or more signs of neurological deficit including ataxia, convulsions, limb paralysis, poor righting reflex, roll-over and coma [41]. Presentation of these signs were evaluated and scored to better assess severity of ECM in mice [44].

\section{Assessment of NRG-1 and artemether treatment in mice infected with or without $\mathrm{PbA}$}

Mice were selected and randomized into treatment groups after diagnosis with ECM on day 5 to 6 post infection. For survival experiments, 11 mice per group were used to obtain significant statistical data. To determine the therapeutic benefit of NRG-1 on ECM-associated brain damage 
and mortality and to compare NRG-1 with artemether (ARM) treatment, $\mathrm{PbA}$-infected mice were treated daily via i.p. injection with $50-\mu \mathrm{l}$ doses of NRG-1 (1.25 ng/kg/day, EGF-like domain, R \& D Systems, Minneapolis, MN, USA) [NP_039250] or artemether prepared in coconut oil (25 mg/kg/day, Sigma-Aldrich, St Louis, MO, USA), from day 6 to day 9 post infection. PbA-infected mice treated daily with $50 \mu \mathrm{l}$ saline solution (i.p.) from day 6 to day 9 post infection were used as the control. Mice were checked several times daily for mortality and signs of ECM neurological symptoms such as ataxia, loss of reflex and hemiplegia. All murine ECM experiments were terminated 19 days after PbA infection with animals euthanized accordingly. Parasite load was monitored periodically (beginning on day 5 post infection) by Giemsa staining of thin blood smears and assessed by counting the number of pRBCs per 1,000 erythrocytes.

\section{Assessment of leukocyte accumulation in brain parenchymal vessels during murine ECM in PbA-infected mice by H\&E staining}

To determine the effect of NRG-1 and ARM treatment on leukocyte accumulation in brain parenchymal vessels during murine ECM pathogenesis, PbA-infected C57BL/ $6 \mathrm{~J}$ mice were anesthetized with isoflurane inhalation and euthanized on day 5 and day 11 post infection. Mice were perfused with $10 \mathrm{ml}$ of cold sterile phosphatebuffered saline to clear vessels of blood prior to collection of brain tissue (three mice per time point per treatment group). Whole brains were stored in formalin for fixation, embedded in paraffin, and sectioned at $10 \mu \mathrm{m}$. Sagittal sections of the brain (day 5 and day 11 post infection) were fixed in $4 \%$ paraformaldehyde and blocked with horse serum for 30 minutes at room temperature. Sections were stained with $\mathrm{H} \& \mathrm{E}$ and leukocytes in the blood vessels were quantified using an ocular grid calibrated with $\mathrm{a} \times$ 400 magnification in an Axioskop 2 Plus microscope (Carl Zeiss Microscopy, Thornwood, NY, USA). The whole area of each section was similarly quantified with the ocular grid calibrated at $\times 40$ magnification. Digital photos were captured by a high-resolution AxioCam HRc camera (Carl Zeiss Microscopy).

\section{Determination of the effect of NRG-1 on mRNA expression of factors involved in vascular endothelial activation and BBB integrity}

To determine the effect of NRG-1 on mRNA expression of factors involved in vascular endothelial activation and $\mathrm{BBB}$ integrity, whole brain tissue from $\mathrm{PbA}$-infected mice treated with either saline, ARM or NRG-1 (three mice per group per time point) was collected and homogenized in Trizol reagent (Life Technologies, Gaithersburg, MD, USA) and total RNA was extracted using RNeasy Mini Kit (Qiagen, Valencia, CA, USA).
Briefly, chloroform $(0.2 \mathrm{ml})$ was added to the homogenate, and the lysate mixed thoroughly. After centrifuging at $12,000 \times \mathrm{g}$ for 20 minutes at $4^{\circ} \mathrm{C}$, the aqueous layer was transferred to a new tube. RNA was precipitated with $500 \mu \mathrm{l}$ of isopropanol and pelleted by centrifuging at $12,000 \times \mathrm{g}$ for 20 minutes at $4^{\circ} \mathrm{C}$. RNase-Free DNase Set (Qiagen) was used according to the manufacturer's instructions to remove contaminating genomic DNA. DNase-treated RNA samples were subsequently stored at $-80^{\circ} \mathrm{C}$ until ready to use. Reverse transcription of RNA samples was performed prior to quantitative PCR. cDNA was synthesized from up to $2 \mu \mathrm{g}$ of total RNA iScript $^{\text {Tw }}$ cDNA Synthesis Kit (Bio-Rad Laboratories, Hercules, CA, USA) using Multigene Gradient Thermal cycler (Labnet International, Inc. Edison, NJ, USA). The resulting cDNA was diluted 1:10 by addition of $180 \mu \mathrm{l}$ of distilled water for quantitative PCR analysis. The primer sequences used for quantitative PCR are described in Table 1.

The quantitative real-time PCR assay was performed using Bio-Rad C1000 thermal cycler (Bio-Rad Laboratories). Approximately $20 \mathrm{ng}$ of cDNA was used in each $25 \mu \mathrm{l}$ PCR reaction using the Bio-Rad $\mathrm{iQ}^{\mathrm{m}} \mathrm{SYBR}^{\circ}$ Green Supermix (Bio-Rad Laboratories, Hercules, CA) and $50 \mu \mathrm{M}$ of each primer. After a 15-minute incubation at $95^{\circ} \mathrm{C}$, amplification was achieved by 39 cycles of a 15 -s denaturation incubation at $95^{\circ} \mathrm{C}$, followed by a 30-s annealing incubation at $55^{\circ} \mathrm{C}$ and 30 -s extension incubation at $72^{\circ} \mathrm{C}$. The identity and purity of the PCR product was confirmed by using dissociation curves and by checking the melting temperature of the PCR product, independently of the PCR reaction. To determine the relative amount of target cDNA present, the cycles to threshold $(\mathrm{Ct})$ values of the target genes were compared with the basal expression of the housekeeping gene, hypoxanthine guanine phosphoribosyltransferase (HPRT). The average amount of HPRT present in each mouse group was used to normalized the quantity of target mRNA sequence against total RNA in each reaction. The differences in $\mathrm{Ct}$ values between HPRT and target gene of day 11 after infection of each group were compared with day 5 after infection-untreated control samples to determine the relative change in mRNA expression.

\section{Assessment of NRG-1 effects on expression of immune determinants of $\mathrm{CM}$ severity}

To determine the effect of NRG-1 and ARM treatment on cytokine/chemokine levels, serum collected from blood harvested via cardiac puncture at pre-treatment (day 0 and day 5) and post treatment (day 11) from anesthetized mice (three to four mice per treatment group per day; pooled) was measured for levels of TNF $\alpha$, IL-1 $\alpha$, IL-6, chemokine (C-X-C motif) ligand 10 (CXCL10), granulocyte colony stimulating factor (G-CSF), IL-5, and 
Table 1 Primer sequences used

\begin{tabular}{lll}
\hline Target gene or mRNA & Primer $\mathbf{5}^{\prime} \mathbf{-} \mathbf{3}^{\prime}$ & \\
\cline { 2 - 3 } & Forward & Reverse \\
\hline HPRT & GCTTTCCCTGGTTAAGCAGTACA & CAAACTTGTCTGGAATTTCAAATC \\
ICAM-1 & GCCTCCGGACTTCGATCTT & GTCAGGGGTGTCGAGCTTTG \\
ANG-1 & ATGCTGTTCAAAACCACACG & TाTCAAGTCGGGATGTTTGAT \\
ANG-2 & ATGTGGTGCAGAACCAGACA & GCAGCTCGAGTCTTGTCGTC \\
C/EBP $\boldsymbol{\beta}$ & TCTACTACGAGCCCGACTGC & AGGTAGGGGCTGAAGTCGAT \\
\hline
\end{tabular}

IL-13. Pooled serum samples were evaluated using Milliplex MAP mouse Cytokine/Chemokine bead-based immunoassay (Millipore, Billerica, MA, USA) coupled with the Luminex $200^{\mathrm{TM}}$ system (Austin, TX, USA) according to the manufacturer's protocol. Samples were tested at a 1:2 dilution using optimal concentrations of standards and antibodies according to the manufacturer's protocol.

\section{Statistical analysis}

Results were expressed as means \pm SD from at least three separate experiments performed in triplicate unless otherwise stated. Differences between means among the treatment groups were analyzed by using the Student $t$ test or one-way analysis of variance (ANOVA) with Holm-Sidak post-test methods where appropriate. Differences in survival among treatment groups were analyzed with Mantel-Cox log rank test. A P-value less than 0.05 was considered significant. Statistical analysis was performed with SigmaPlot (Version 10.0) with SigmaStat (Version 3.5) software for windows.

\section{Ethics statement}

This study was carried out in strict accordance with the recommendations in the Guide for the Care and Use of Laboratory Animals of the National Institutes of Health. The Institutional Animal Care and Usage Committee
(IACUC) of Morehouse School of Medicine (Permit Number 09-06) approved all protocols.

\section{Results}

NRG-1 therapy attenuates ECM-associated mortality

To test whether NRG-1 improves survival from ECM, $\mathrm{PbA}$-infected $C 57 \mathrm{BL} / 6 \mathrm{~J}$ mice were treated with recombinant human NRG-1 (1.25 ng/kg/day) or ARM (25 mg/kg/day). ECM-associated mortality was observed between days 5 and 12 post infection in PbA-infected mice sham-treated with saline, with mortality between $30 \%$ and $100 \%$ (Figure 1A). ARM treatment reduced mortality by $82 \%$ ( $P<0.001$, Mantel-Cox, log rank) compared to saline treatment (Figure 1A). Mice treated with NRG-1 showed significantly reduced mortality at $73 \%(P<0.01$, Mantel-Cox, log rank) compared to saline treatment (Figure 1A).

NRG-1 effect on parasite load was assessed before and after treatment. Parasite load in saline-treated mice increased markedly from day 5 to day 11 post infection by which time all the mice had been euthanized (Figure 1A and B). ARM treatment significantly reduced parasite load in $\mathrm{PbA}$-infected mice as expected from $21 \%$ on day 5 post infection to $<5 \%$ by day 11 post infection when compared with saline-treated mice on day 11 post infection, $P<0.001$ (Figure 1B). NRG-1-treated
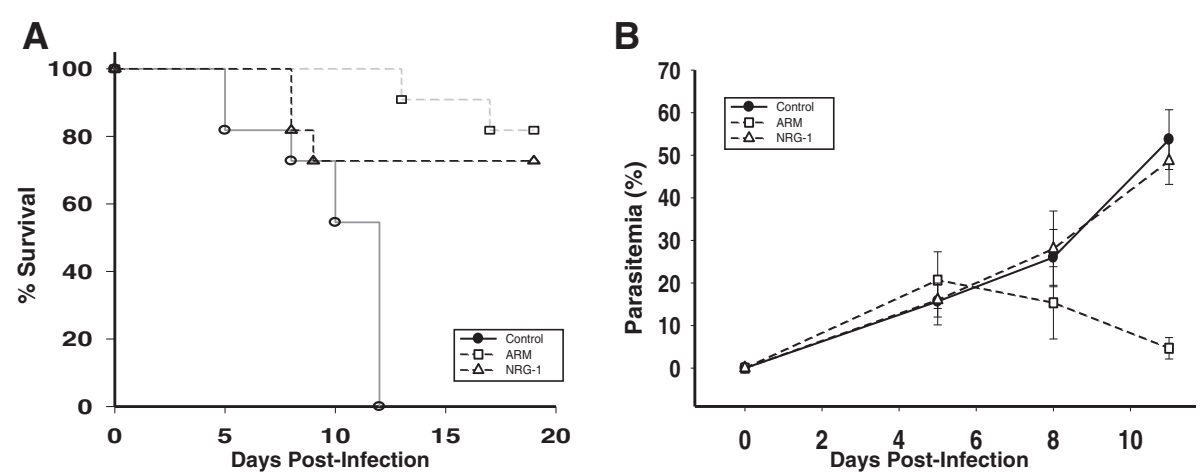

Figure 1 Neuregulin-1 (NRG-1) therapy protects $73 \%$ of mice from fatal murine experimental cerebral malaria (ECM). Plasmodium berghei ANKA (PbA)-infected mice were treated intraperitoneally from day 6 to 9 post-infection with NRG-1 at $1.25 \mathrm{ng} / \mathrm{kg} / \mathrm{day}(\mathrm{n}=11)$ and artemether $(A R M)$ at $25 \mathrm{mg} / \mathrm{kg} /$ day $(n=11)$. (A) Survival improved after NRG-1 and ARM treatment compared to saline treatment $(P<0.001$, log rank test). (B) Parasite load was measured as the number of parasitized red blood cells (RBCs) in at least 1,000 RBC. The experiment is representative of three independent infections. Results shown are mean \pm SD. 
mice demonstrated improved survival despite no significant difference in parasite load compared to saline-treated mice (Figure 1A and B) suggesting that NRG-1 mediated attenuation of ECM was not via the reduction of parasite burden.

\section{NRG-1 treatment reduces leukocyte accumulation in brain microvasculature of $\mathrm{PbA}$-infected mice}

Marked leukocyte adherence and accumulation in brain vessels is linked to brain inflammation and is critical for murine ECM pathogenesis $[41,45]$. To determine the effect of NRG-1 therapy on brain inflammation in PbAinfected mice, the number of adherent leukocytes was quantified after treatment with NRG-1 on day 11 post infection. The numbers of leukocytes per vessel and per $\mathrm{mm}^{2}$ decreased after NRG-1 treatment when compared with saline treatment (Figure 2). Brain microvessels in mice treated with ARM showed significant reduction in leukocyte accumulation by day 11 post infection compared to saline-treated mice (Figure 2). Although NRG-1treated mice had high peripheral parasitemia compared to ARM-treated mice, there were no significant differences in the accumulation of leukocytes in the brains of NRG-1treated mice and ARM-treated mice (Figure 2).

\section{NRG-1 treatment decreases activation of brain vascular endothelium and promotes BBB stability in PbA-infected mice}

Overproduction of pro-inflammatory factors promotes vascular endothelial activation and is deleterious to BBB integrity [46]. To investigate the effect of NRG-1 on activation of brain vascular endothelium and $B B B$ integrity during ECM, mRNA levels of specific protein markers (angiopoietin-1 and -2, CCAAT enhancer-binding protein $(\mathrm{C} / \mathrm{EBP}) \beta$, and intercellular adhesion molecule-1 (ICAM-1)) that mediate endothelial activation [47-49] and BBB breakdown [50,51] were assessed.

Angiopoietin-1 and angiopoietin-2 are antagonistic regulators of endothelial cell activation and BBB function and integrity and are functional biomarkers that are used to predict fatal CM [52-54]. Expression of angiopoietin-1, a marker of vascular endothelial quiescence and BBB stability, increased in brain tissue of mice treated with NRG-1 compared with saline-treated mice, $P<0.001$ (Figure 3A). However, there was no significant difference in angiopoietin-1 levels between saline-treated and ARM-treated mice on day 11 when compared to day- 5 untreated mice (Figure 3A). Expression of angiopoietin-2, a marker for $\mathrm{BBB}$ dysfunction, was significantly reduced in brain tissue of infected mice treated with NRG-1 compared to salinetreated mice, $P<0.001$ (Figure 3B). Conversely, expression of angiopoietin-2 increased significantly on day 11 in saline-treated and ARM-treated mice compared to day- 5 untreated mice, $P<0.001$ (Figure $3 \mathrm{~B}$ ).

$\mathrm{C} / \mathrm{EBP} \beta$ is a critical regulator of acute-phase proinflammatory genes involved in host response to infections $[55,56]$ and is implicated in the release of inflammatory and adhesion factors such as IL-6, TNFo, CD40, ICAM-1 and bioactive tachykinins responsible

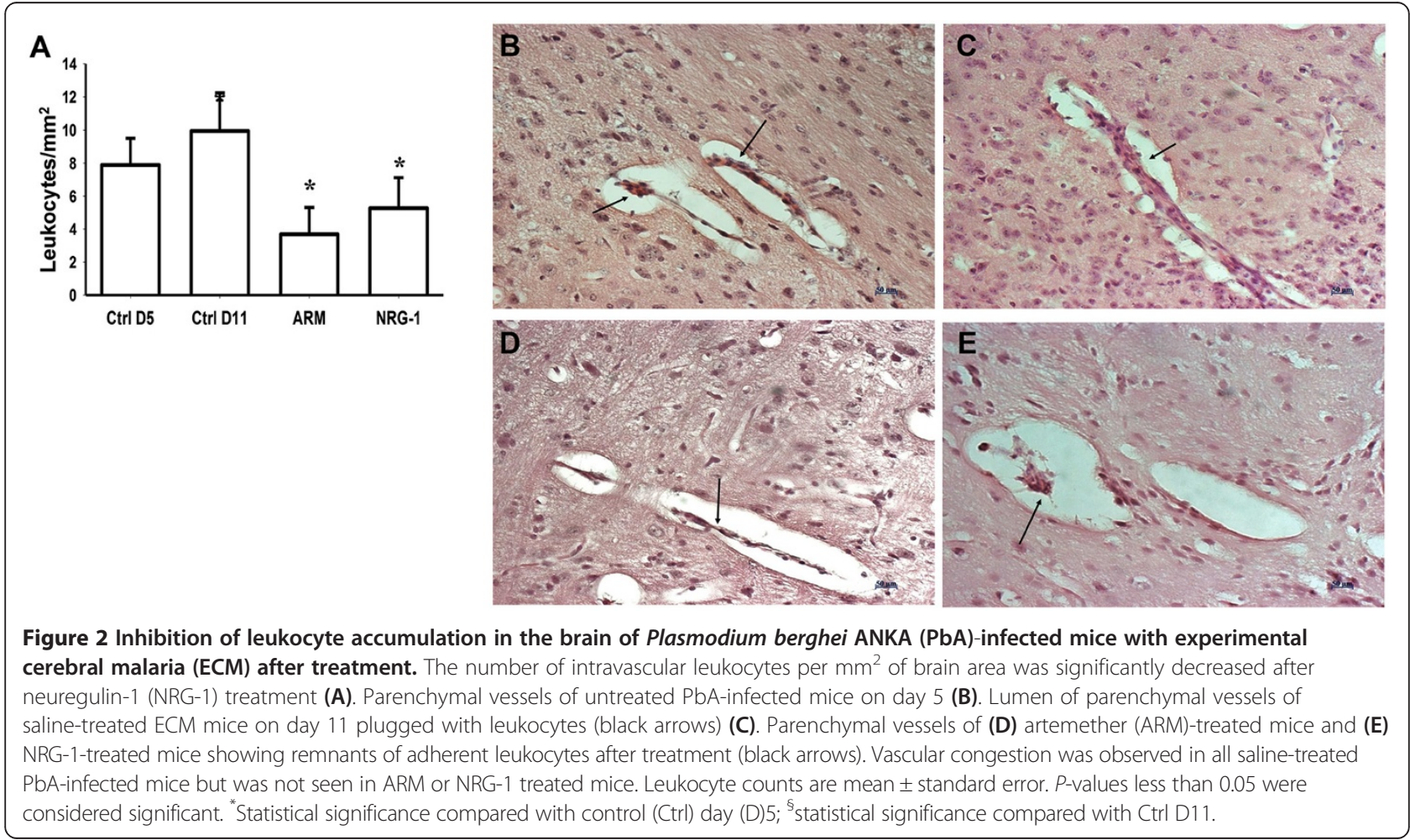




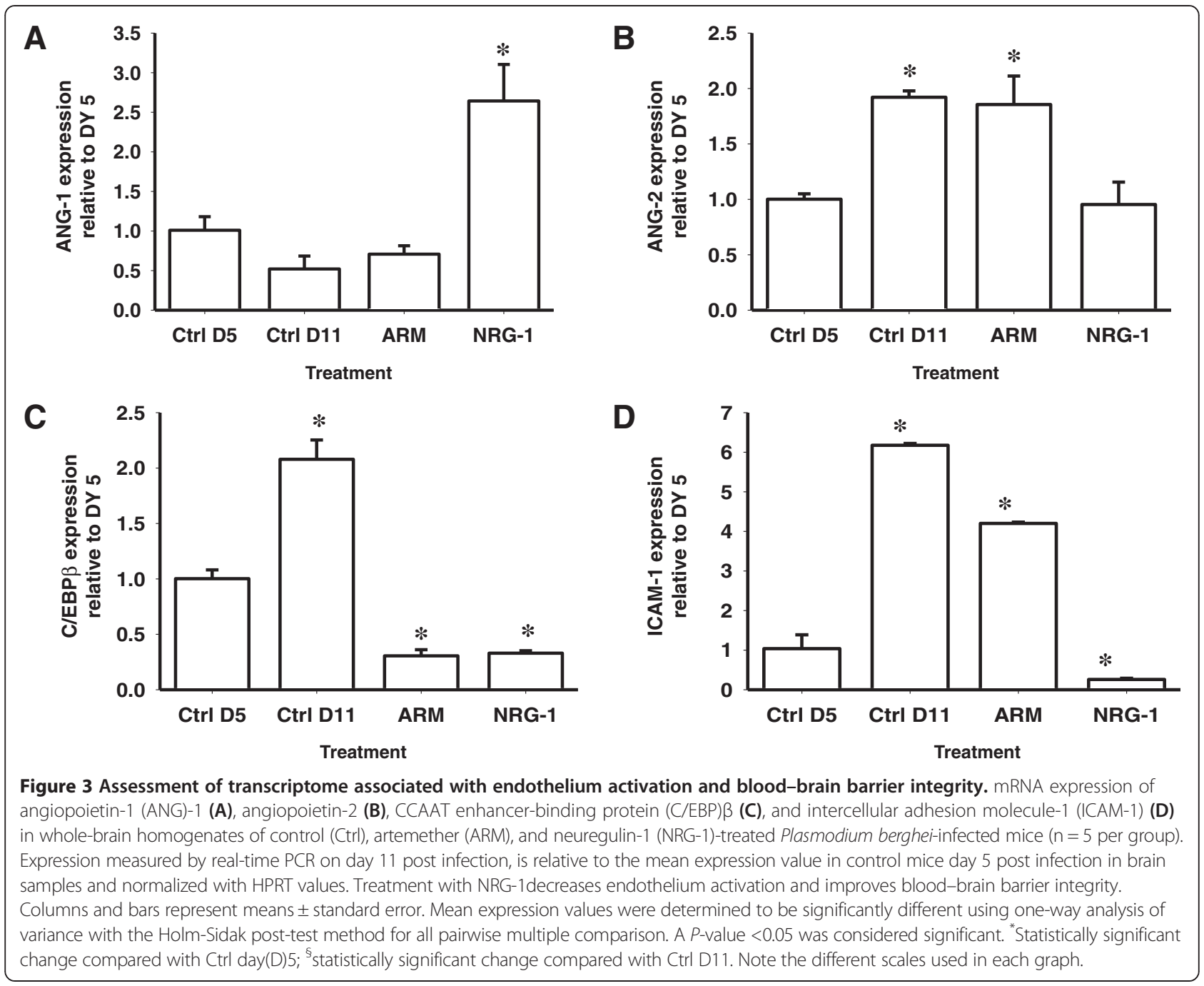

for neuroinflammation and tissue repair in the central nervous system [57-62]. C/EBP $\beta$ expression was significantly reduced in ARM-treated and NRG-1-treated mice compared to saline-treated mice, $P<0.001$ (Figure 3C). Expression of $\mathrm{C} / \mathrm{EBP} \beta$ increased significantly in the brains of saline-treated mice when compared to day 5 untreated mice, $P<0.001$ (Figure 3C). Expression of ICAM-1 which directly correlates with endothelial activation $[47,63,64]$ was significantly reduced in brain of NRG-1 treated mice compared to saline-treated mice, $P<0.001$ (Figure 3D). ICAM-1 expression in NRG-1-treated mice was reduced to levels lower than that observed in day- 5 untreated mice (Figure 3D). However, ICAM-1 expression increased significantly in saline-treated and ARM-treated mice compared to day- 5 untreated controls, $P<0.001$ (Figure 3D).

\section{NRG-1 treatment modulates immune determinants of CM} severity

Dysregulation of host pro-inflammatory factors plays a critical role in the pathogenesis of human $\mathrm{CM}$ and murine ECM. Previous studies showed overexpression of pro-inflammatory cytokines TNF $\alpha$, IL- $1 \alpha$ and IL- 6 in CM patients promotes pathogenesis of CM (acute immune activation, promotion of adhesion molecules, leukocyte recruitment, fever and BBB disruption) and were associated with severe and lethal malaria [20,65-71]. We recently established that elevated levels of anti-angiogenic and apoptotic factor CXCL10 are associated with fatal CM in humans [72-74]. Moreover, CXCL10 plays a critical role in the development of murine ECM [75]. TNF $\alpha$ levels in saline-treated mice at day 11 increased significantly compared to untreated mice at day 5, $P<0.05$ (Figure 4A). However, TNF $\alpha$ serum levels were reduced in mice treated with NRG-1 and ARM compared to saline-treated mice, $P<0.001$ (Figure 4A). NRG-1 therapy significantly reduced serum IL-1 $\alpha$ and IL- 6 levels compared to salinetreated mice, $P<0.001$ (Figure 4B, C). Similarly, ARM treatment reduced serum levels of IL-1 $\alpha$ and IL-6 compared to saline-treated mice, $P<0.001$ (Figure 4B, C). CXCL10 levels in saline-treated mice at day 11 increased 


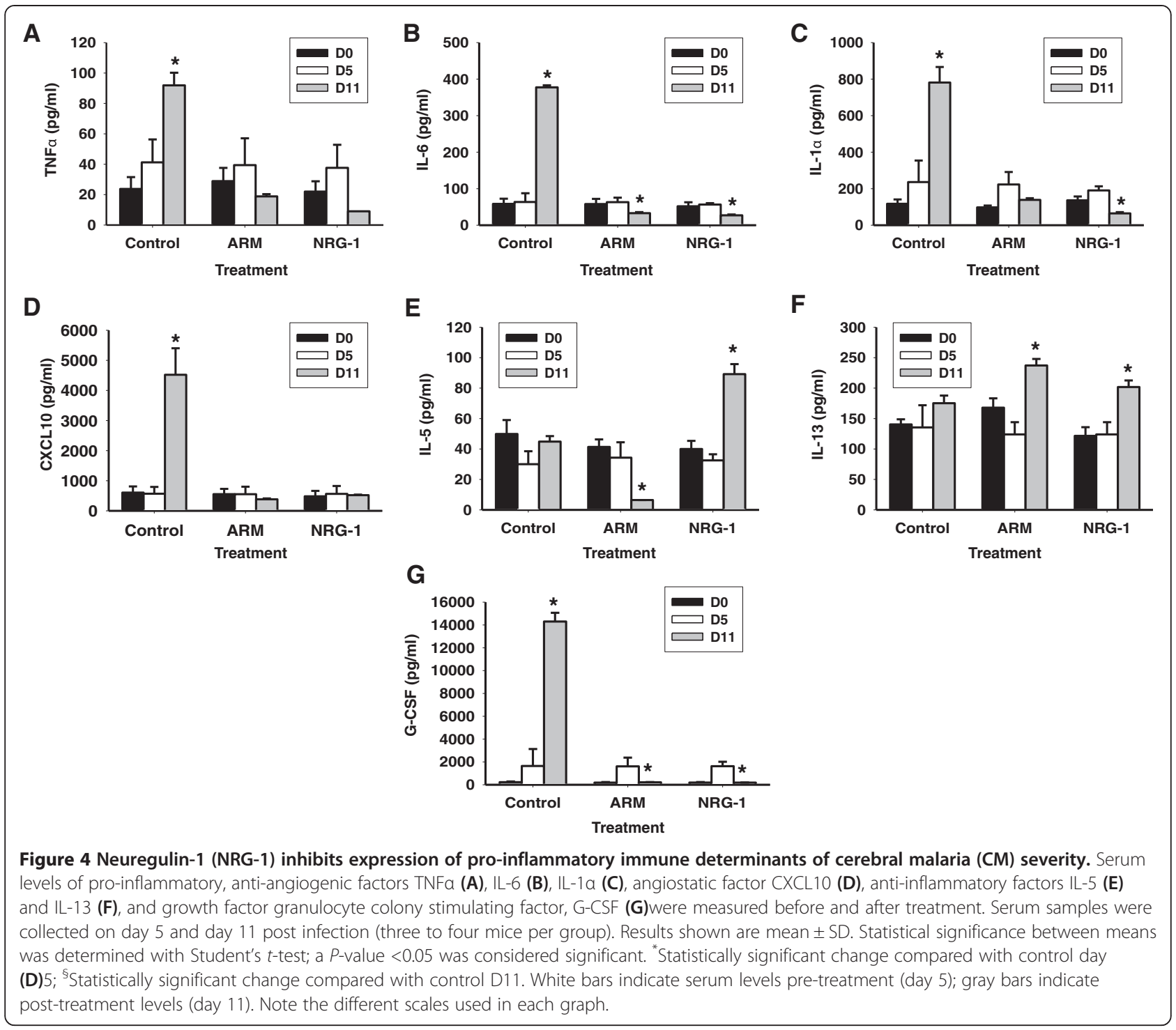

significantly compared to untreated mice at day 5, $P<0.001$ (Figure 4D). Conversely, CXCL10 levels in mice treated with NRG-1 and ARM were significantly reduced at day 11 compared to saline-treated mice, $P<0.001$ (Figure 4D). In contrast, Th2 cytokines IL-5 and IL-13 associated with reduced severity of disease and increased protection against CM [76-79] were significantly elevated in serum after treatment with NRG-1compared to saline-treated mice, $P<0.001$ (Figure 4E, F). ARM therapy increased expression of IL-13 in PbA-infected mice although serum levels of IL-5 were markedly reduced after ARM treatment, $P<0.001$ (Figure 4E, F). Furthermore, increased levels of G-CSF, a neuronal growth factor, discriminate CM patients with poor disease outcome $[20,80]$. G-CSF levels increased significantly in saline-treated mice at day 11 compared to untreated mice at day $5, P<0.001$
(Figure 4G). G-CSF levels were significantly reduced in infected mice treated with ARM and NRG-1 compared to saline-treated mice, $P<0.001$ (Figure 4G).

\section{Discussion}

Despite prompt administration of optimal antimalarial treatment, mortality associated with $\mathrm{CM}$ remains unacceptably high, thus, prompting the development of adjunct therapeutics that can reduce or prevent CM pathology and associated mortalities [12,13] Recent studies have shown that NRG-1 was effective in treating $\mathrm{ABI}$ such as AIS and acute neurotoxin exposure by preventing neuroinflammation and neuronal tissue death $[35,36]$, which are similar to those observed in CM. Furthermore, NRG-1 stabilizes the BBB and mediates inflammatory pathways to prevent tissue damage associated with 
brain injury $[32,33,37]$. Using a PbA ECM model that mimics significant features of human $\mathrm{CM}$, we have demonstrated the effectiveness of NRG-1 therapy against ECM pathophysiology, and associated mortality.

Advances in drug therapies that eradicate malaria parasites are still unable to prevent mortality in up to $30 \%$ of CM patients. In humans, quinine and artemisinin derivatives (artesunate and artemether) are the mainstream drugs used to treat CM $[81,82]$. ARM was selected for use in this study as previous research has demonstrated that ARM was more effective against murine ECM than quinine, artemisinin and artesunate [41]. Despite anti-parasitic properties of ARM, mortality rates were as high as $18 \%$ in mice treated with ARM in the current study. However, no evidence of neurological dysfunction associated with ECM was observed in ARM-treated mice. This unacceptably high mortality in ARM-treated mice may be due to low efficacy of ARM against $\mathrm{PbA}$ that can lead to recrudescence and malarial anemia post treatment [41]. Furthermore, therapies targeting parasite eradication without addressing secondary effects of parasite infection, such as tissue damage and neurological complications, are inadequate for preventing mortalities. Thus, there is great need for adjunct therapeutics that target CM pathology that in conjunction with parasite-eradicating antimalarial agents can prevent mortality associated with CM.

Permanent or reversible neurological sequelae such as coma, residual epilepsy and cognitive deficits, are common clinical outcomes in CM patients. These neurological outcomes are associated with inflammatory cascades initiated by pathogen toxins that lead to widespread endothelial activation and brain damage (petechial hemorrhage and neuronal cell death) and involves inflammationinduced sequestration of infected RBCs [83-85]. Similarly, accumulation of leukocytes occurs in brain microvessels of $\mathrm{PbA}$-infected mice that leads to vascular congestion and contributes to brain damage. [86,87]. Although parasitemia levels were high in PbA-infected mice treated with NRG-1, there was significant reduction in leukocyte accumulation in brain microvessels after NRG-1 treatment. This indicates that NRG-1 therapy effectively reduces brain inflammation associated with ECM pathogenesis even in the presence of high parasitemia.

Human CM and murine ECM are characterized by a dysregulated immune response leading to overexpression of pro-inflammatory cytokines including TNF $\alpha$, IL- $1 \alpha$, IL-6, and CXCL10 [67-69,74,75]. These cytokines are secreted by T-cells, macrophages and endothelial cells in response to infection and play several roles that include promotion of acute immune response, leukocyte recruitment, BBB disruption and negative hypothalamic mediation during febrile illness [66,70,88-93]. Plasma and cerebrospinal fluid levels of TNF $\alpha$, IL- $1 \alpha$ and IL-6 are increased in children with CM [20,68] suggesting their role in human CM. We previously reported that increased plasma and cerebrospinal fluid levels of CXCL10 predict fatal CM [72-74] and mice deficient in the CXCL10 gene are partially protected against murine ECM [75]. NRG-1 therapy significantly reduced serum TNF $\alpha$, IL-1 $\alpha$, IL-6, and CXCL10 levels while improving survival against ECM. High serum levels of the growth factor G-CSF have been shown to correlate with fatal CM in humans [80]. However, NRG-1 reduced G-CSF, suggesting amelioration of pathogenic pathways that leads to induction of G-CSF observed in fatal CM $[20,80]$. Thus, further study is warranted to determine the role of G-CSF in severe disease and the NRG-1 protective effect in reducing G-CSF production. Furthermore, there is growing evidence of the role for antiinflammatory factors, IL-5 and IL-13 in protection against malarial disease. In a population of south Asian malaria patients, increased levels of IL-5 was associated with reduced severity of disease [79]. Genetic studies in African and south-east Asian populations have linked IL-13 to protection against cerebral malaria and show that polymorphisms that alter IL-13 production may increase risk of severe malaria [76-78]. In the present study, NRG-1 enhanced production of IL-5 and IL-13, and suggests NRG-1 promotes anti-inflammatory factors while dampening pro-inflammatory factors to ameliorate CM pathogenesis.

Angiopoietin-1 (a biomarker of endothelium quiescience and stability) and vascular permeability factor angiopoietin-2 (marker of vascular barrier breakdown) are potent modulators of vascular inflammation, endothelial activation and BBB function [49,94-96]. Angiopoietin-1 stabilizes the vascular endothelium barrier [97] and regulates the activity of $\mathrm{BBB}$ permeability factors such as plateletactivating factor (PAF), vascular epithelial growth factor (VEGF), ELAM-1, bradykinin, thrombin and histamine [98-101]. Increased activity of angiopoietin-1 promotes endothelial survival $[102,103]$, modulates plasma leakage $[100,104,105]$ and reduces vascular inflammation by inhibiting ICAM-1, vascular cell adhesion molecule-1 (VCAM-1) and E-selectin expression [106]. Conversely, pro-inflammatory cytokines TNF- $\alpha$, IL- $1 \beta$ and vascular permeability factor, VEGF, mediate the release of angiopoietin-2, an antagonist to angiopoietin-1 $[48,107]$, that promotes increased vascular inflammation [108], disruption of angiogenesis [109], endothelial cell death [110] and vascular regression [110,111]. Moreover, angiopoietin-2 expression is elevated in response to endothelial activation, hypoxia and ischemia [107,112-114]. In human CM, high levels of angiopoietin-2 and low levels of angiopoietin-1 are linked to CM severity and studies suggest these angiogenic factors function as prognostic biomarkers that can discriminate severe $\mathrm{CM}$ from mild malaria and predict 
fatal CM outcome [53,54]. Nakaoka et al. show that NRG-1 stimulates expression of angiopoietin-1 [115] and increased expression of angiopoietin-1 inhibits release or activity of angiopoietin-2 [107,116]. In the present study, NRG-1 treatment increased expression of angiopoietin-1, thus promoting endothelial barrier function and integrity during ECM, while modulating angiopoietin-2 expression in the brains of PbA-infected mice.

Parasite sequestration and activation of endothelial cells by infected erythrocytes and pro-inflammatory cytokines are hallmark events in the brain pathology of pediatric CM patients $[64,117,118]$. Parasite sequestration and endothelial activation correlate with an increase in adhesion molecules such as ICAM-1 and VCAM-1 that bind infected erythrocytes, influence leukocyte migration and promote further release of pro-inflammatory cytokines [119-121]. ICAM-1 is a marker of endothelial activation whose expression is upregulated on the vascular endothelium in the brain in murine and human $\mathrm{CM}$ $[64,122-124]$. ICAM expression is induced by pro-inflammatory cytokines such as TNF- $\alpha$, IFN- $\gamma$ and VEGF $[47,125,126]$. In human CM, increased ICAM-1 levels are associated with disease severity $[63,119,127]$. Furthermore, murine ECM studies show increased expression of ICAM-1 contributes to the development of ECM $[47,128,129]$. Previous studies indicate NRG-1 reduces the expression of ICAM-1 following ischemic stroke [32]. NRG-1 increases activity of PI3-kinase $[130,131]$ which suppresses VEGF-mediated expression of ICAM-1 on endothelial cells $[106,126]$. Additionally, $\mathrm{C} / \mathrm{EBP} \beta$ is a critical regulator of acute host-response to infections and neuroinflammation [55-58,60] that stimulates release of inflammatory and adhesion factors such as IL-6, TNF $\alpha$, CD40 and ICAM-1, thus contributing to ECM development [56-59,61]. In this study, NRG-1 treatment of murine ECM demonstrated inhibition of ICAM-1 and C/EBP $\beta$ in the ECM brain while reducing leukocyte adhesiveness and accumulation in brain microvessels.

NRG-1 was recently used as a treatment for heart failure and showed significant efficacy for improving cardiac function in a phase-II patient study [132-134]. In this study, patients received placebo or NRG-1 at a dose of 0.3 to $1.2 \mu \mathrm{g} / \mathrm{kg} /$ day intravenously for 10 days, in addition to standard drug therapies. During a follow-up period 11 to 90 days after study initiation, NRG-1 significantly improved heart function in patients and the effective doses were shown to be safe and tolerable. Two additional clinical trials to determine the ability of NRG1 to improve cardiac function after heart failure have been initiated in the US (ClinicalTrails.gov identifiers NCT01258387 and NCT01541202). During the period of study, no severe events were observed in either healthy or impaired patients.

\section{Conclusions}

The use of recombinant human NRG-1 against acute brain injury is being tested in experimental models [32,34-36,135,136]. Recent and ongoing clinical trials provide evidence indicating efficacy and safety of recombinant human NRG-1 against chronic heart failure and vascular remodeling [132-134]. The efficacy of NRG-1 treatment against murine ECM provides compelling evidence for developing NRG-1 and NRG-like drugs for the treatment and management of CM patients. By inhibiting systemic and brain inflammation resulting from ECM pathogenesis, NRG-1 therapy improved survival in mice with late-stage ECM. The ability of NRG-1 to affect a range of functionally related CM inflammatory mediators increases the likelihood that such an effect will translate to human $\mathrm{CM}$ to protect against human $\mathrm{CM}$ pathologies. We propose further investigation of NRG-1 as a supportive therapy alongside current antimalarial agents in the management of CM.

\section{Abbreviations}

$A B I$ : Acute brain injury; AIS: Acute ischemic stroke; ANOVA: Analysis of variance; ARM: Artemether; BBB: Blood-brain barrier; C/EBP: CCAAT enhancer-binding protein; CM: Cerebral malaria; Ct: Cycles to threshold; CXCL: Chemokine (C-X-C motif) ligand; ECM: Experimental cerebral malaria; G-CSF: Granulocyte colony stimulating factor; H\&E: Hematoxylin and eosin; ICAM: Intercellular adhesion molecule-1; IL: Interleukin; i.p.: Intraperitoneal; NRG-1: Neuregulin-1; PbA: Plasmodium berghei ANKA; pRBC: PbA-infected red blood cell; RBC: Red blood cell; TBI: Traumatic brain injury; TNF: Tumor necrosis factor; VEGF: Vascular epithelial growth factor; VCAM-1: Vascular cell adhesion molecule-1.

\section{Competing interests}

The authors declare that they have no competing interests.

\section{Authors' contributions}

WS designed and performed experiments, analyzed data and wrote the paper. NW performed experiments, analyzed data and wrote the paper. LA designed and performed experiments. SP designed and performed experiments. JP designed experiments and analyzed data. ML designed and performed experiments and analyzed data. BF designed experiments, analyzed data and assisted in the drafting this manuscript. JS conceived the study, designed and supervised experiments and assisted in the drafting this manuscript. All authors read and approved the final manuscript.

\section{Acknowledgements}

We thank Morehouse School of Medicine (MSM) Center for Laboratory Animal Resources staff for technical assistance in animal experiments. This work was financially supported by the National Institutes of Health grant numbers NIH-FIC (1T90-HG004151-01) for postdoctoral training in Genomics and Hemoglobinopathies, NIH/FIC/NINDS R21, NIH/NIMHD/8G12 MD007602, NHI-U01 NS 057993, NIH-U54 NS060659 and the CounterACT Program, NIH/NINDS/U01 NS 057993.

\section{Author details}

${ }^{1}$ Department of Microbiology, Biochemistry and Immunology, Morehouse School of Medicine, Atlanta, GA, USA. ${ }^{2}$ Cardiovascular Research Institute Morehouse School of Medicine, Atlanta, GA, USA. ${ }^{3}$ Department of Pathology Morehouse School of Medicine, Atlanta, GA, USA. ${ }^{4}$ Department of Neurobiology, Neuroscience Institute, Morehouse School of Medicine, Atlanta, GA, USA

Received: 20 September 2013 Accepted: 23 December 2013 Published: 17 January 2014 


\section{References}

1. World Health Organization: World Malaria Report 2011. http://www.who. int/malaria/world_malaria_report_2011/WMR2011_noprofiles_lowres.pdf.

2. Bondi FS: The incidence and outcome of neurological abnormalities in childhood cerebral malaria: a long-term follow-up of 62 survivors. Trans R Soc Trop Med Hyg 1992, 86:17-19.

3. Brewster DR, Kwiatkowski D, White NJ: Neurological sequelae of cerebral malaria in children. Lancet 1990, 336:1039-1043.

4. Holding PA, Stevenson J, Peshu N, Marsh K: Cognitive sequelae of severe malaria with impaired consciousness. Trans R Soc Trop Med Hyg 1999, 93:529-534.

5. Idro R, Kakooza-Mwesige A, Balyejussa S, Mirembe G, Mugasha C Tugumisirize J, Byarugaba J: Severe neurological sequelae and behaviour problems after cerebral malaria in Ugandan children. BMC Res Notes 2010, 3:104.

6. Boivin MJ, Bangirana P, Byarugaba J, Opoka RO, Idro R, Jurek AM, John CC: Cognitive impairment after cerebral malaria in children: a prospective study. Pediatrics 2007, 119:e360-e366

7. Murphy SC, Breman JG: Gaps in the childhood malaria burden in Africa: cerebral malaria, neurological sequelae, anemia, respiratory distress, hypoglycemia, and complications of pregnancy. Am J Trop Med Hyg 2001, 64(Suppl 1-2):57-67.

8. Meremikwu MM, Asindi AA, Ezedinachi E: The pattern of neurological sequelae of childhood cerebral malaria among survivors in Calabar, Nigeria. Cent Afr J Med 1997, 43:231-234.

9. Idro R, Marsh K, John CC, Newton CR: Cerebral malaria: mechanisms of brain injury and strategies for improved neurocognitive outcome. Pediatr Res 2010, 68:267-274.

10. Newton CR, Krishna S: Severe falciparum malaria in children: current understanding of pathophysiology and supportive treatment. Pharmacol Ther 1998, 79:1-53.

11. Dondorp A, Nosten F, Stepniewska K, Day N, White N: Artesunate versus quinine for treatment of severe falciparum malaria: a randomised trial. Lancet 2005, 366:717-725.

12. Mishra SK, Wiese L: Advances in the management of cerebral malaria in adults. Curr Opin Neurol 2009, 22:302-307.

13. Mohanty S, Patel DK, Pati SS, Mishra SK: Adjuvant therapy in cerebral malaria. Indian J Med Res 2006, 124:245-260.

14. John CC, Kutamba E, Mugarura K, Opoka RO: Adjunctive therapy for cerebral malaria and other severe forms of Plasmodium falciparum malaria. Expert Rev Anti Infect Ther 2010, 8:997-1008.

15. Day NP, Hien TT, Schollaardt T, Loc PP, Chuong LV, Chau TT, Mai NT, Phu $\mathrm{NH}$, Sinh DX, White NJ, Ho M: The prognostic and pathophysiologic role of pro- and antiinflammatory cytokines in severe malaria. $J$ Infect Dis 1999, 180:1288-1297.

16. Brown $\mathrm{H}$, Turner $\mathrm{G}$, Rogerson $\mathrm{S}$, Tembo M, Mwenechanya J, Molyneux $\mathrm{M}$, Taylor T: Cytokine expression in the brain in human cerebral malaria. $J$ Infect Dis 1999, 180:1742-1746.

17. Hansen DS: Inflammatory responses associated with the induction of cerebral malaria: lessons from experimental murine models. PLoS Pathog 2012, 8:e1003045.

18. Nacer A, Movila A, Baer K, Mikolajczak SA, Kappe SH, Frevert U: Neuroimmunological blood brain barrier opening in experimental cerebral malaria. PLoS Pathog 2012, 8:e1002982.

19. Hunt NH, Grau GE: Cytokines: accelerators and brakes in the pathogenesis of cerebral malaria. Trends Immunol 2003, 24:491-499.

20. John CC, Panoskaltsis-Mortari A, Opoka RO, Park GS, Orchard PJ, Jurek AM, Idro R, Byarugaba J, Boivin MJ: Cerebrospinal fluid cytokine levels and cognitive impairment in cerebral malaria. Am J Trop Med Hyg 2008, 78:198-205.

21. Schofield L, Grau GE: Immunological processes in malaria pathogenesis. Nat Rev Immunol 2005, 5:722-735.

22. Verra F, Mangano VD, Modiano D: Genetics of susceptibility to Plasmodium falciparum: from classical malaria resistance genes towards genome-wide association studies. Parasite Immunol 2009, 31:234-253.

23. Driss A, Hibbert JM, Wilson NO, Iqbal SA, Adamkiewicz TV, Stiles JK: Genetic polymorphisms linked to susceptibility to malaria. Malar $J$ 2011, 10:271.

24. Hill AV: The immunogenetics of resistance to malaria. Proc Assoc Am Physicians 1999, 111:272-277.
25. Taoufiq Z, Pino P, N'Dilimabaka N, Arrouss I, Assi S, Soubrier F, Rebollo A, Mazier D: Atorvastatin prevents Plasmodium falciparum cytoadherence and endothelial damage. Malar J 2011, 10:52.

26. Wilson NO, Solomon W, Anderson L, Patrickson J, Pitts S, Bond V, Liu M, Stiles JK: Pharmacologic inhibition of CXCL10 in combination with anti-malarial therapy eliminates mortality associated with murine model of cerebral malaria. PLoS One 2013, 8:e60898.

27. Achtman AH, Pilat S, Law CW, Lynn DJ, Janot L, Mayer ML, Ma S, Kindrachuk J, Finlay BB, Brinkman FS, Smyth GK, Hancock RE, Schofield L: Effective adjunctive therapy by an innate defense regulatory peptide in a preclinical model of severe malaria. Sci Transl Med 2012, 4:135-164.

28. Li Y, Tennekoon Gl, Birnbaum M, Marchionni MA, Rutkowski JL: Neuregulin signaling through a PI3K/Akt/Bad pathway in Schwann cell survival. Mol Cell Neurosci 2001, 17:761-767.

29. Falls DL: Neuregulins: functions, forms, and signaling strategies. Exp Cell Res 2003, 284:14-30.

30. Talmage DA: Mechanisms of neuregulin action. Novartis Found Symp 2008, 289:74-84. discussion 84-93.

31. Buonanno A, Fischbach GD: Neuregulin and ErbB receptor signaling pathways in the nervous system. Curr Opin Neurobiol 2001, 11:287-296.

32. Xu Z, Ford GD, Croslan DR, Jiang J, Gates A, Allen R, Ford BD: Neuroprotection by neuregulin-1 following focal stroke is associated with the attenuation of ischemia-induced pro-inflammatory and stress gene expression. Neurobiol Dis 2005, 19:461-470.

33. Xu Z, Jiang J, Ford G, Ford BD: Neuregulin-1 is neuroprotective and attenuates inflammatory responses induced by ischemic stroke. Biochem Biophys Res Commun 2004, 322:440-446.

34. Li Y, Xu Z, Ford GD, Croslan DR, Cairobe T, Li Z, Ford BD: Neuroprotection by neuregulin-1 in a rat model of permanent focal cerebral ischemia. Brain Res 2007, 1184:277-283.

35. Li Y, Lein PJ, Liu C, Bruun DA, Giulivi C, Ford GD, Tewolde T, Ross-Inta C, Ford BD: Neuregulin-1 is neuroprotective in a rat model of organophosphate-induced delayed neuronal injury. Toxicol Appl Pharmacol 2012, 262:194-204.

36. Xu Z, Croslan DR, Harris AE, Ford GD, Ford BD: Extended therapeutic window and functional recovery after intraarterial administration of neuregulin-1 after focal ischemic stroke. J Cereb Blood Flow Metab 2006, 26:527-535.

37. Lok J, Zhao S, Leung W, Seo JH, Navaratna D, Wang X, Whalen MJ, Lo EH: Neuregulin-1 effects on endothelial and blood-brain-barrier permeability after experimental injury. Trans/ Stroke Res 2012, 3:S119-S124.

38. Stanimirovic $D$, Satoh $\mathrm{K}$ : Inflammatory mediators of cerebral endothelium: a role in ischemic brain inflammation. Brain Pathol 2000, 10:113-126.

39. Kim JS, Chopp M, Chen H, Levine SR, Carey JL, Welch KM: Adhesive glycoproteins CD11a and CD18 are upregulated in the leukocytes from patients with ischemic stroke and transient ischemic attacks. J Neurol Sci 1995, 128:45-50.

40. Stoll G, Jander S, Schroeter M: Inflammation and glial responses in ischemic brain lesions. Prog Neurobiol 1998, 56:149-171.

41. Clemmer L, Martins YC, Zanini GM, Frangos JA, Carvalho LJ: Artemether and artesunate show the highest efficacies in rescuing mice with late-stage cerebral malaria and rapidly decrease leukocyte accumulation in the brain. Antimicrob Agents Chemother 2011, 55:1383-1390

42. Lackner P, Beer R, Heussler V, Goebel G, Rudzki D, Helbok R, Tannich E, Schmutzhard E: Behavioural and histopathological alterations in mice with cerebral malaria. Neuropathol Appl Neurobiol 2006, 32:177-188

43. Martins YC, Werneck GL, Carvalho L, Silva BP, Andrade BG, Souza TM, Souza DO, Daniel-Ribeiro CT: Algorithms to predict cerebral malaria in murine models using the SHIRPA protocol. Malar J 2010, 9:85.

44. Waknine-Grinberg JH, Hunt N, Bentura-Marciano A, McQuillan JA, Chan HW, Chan WC, Barenholz Y, Haynes RK, Golenser J: Artemisone effective against murine cerebral malaria. Malar 」 2010, 9:227.

45. Belnoue E, Kayibanda M, Vigario AM, Deschemin JC, Van Rooijen N, Viguier $M$, Snounou G, Renia L: On the pathogenic role of brain-sequestered alphabeta CD8+ T cells in experimental cerebral malaria. J Immunol 2002, 169:6369-6375.

46. Faille D, El-Assaad F, Alessi MC, Fusai T, Combes V, Grau GE: Platelet-endothelial cell interactions in cerebral malaria: the end of a cordial understanding. Thromb Haemost 2009, 102:1093-1102. 
47. Favre N, Da Laperousaz C, Ryffel B, Weiss NA, Imhof BA, Rudin W, Lucas R, Piguet PF: Role of ICAM-1 (CD54) in the development of murine cerebral malaria. Microbes Infect 1999, 1:961-968.

48. Fiedler U, Augustin HG: Angiopoietins: a link between angiogenesis and inflammation. Trends Immunol 2006, 27(12):552-558.

49. Fiedler U, Reiss Y, Scharpfenecker M, Grunow V, Koidl S, Thurston G, Gale NW, Witzenrath M, Rosseau S, Suttorp N, Sobke A, Herrmann M, Preissner $K T$, Vajkoczy P, Augustin HG: Angiopoietin-2 sensitizes endothelial cells to TNF-alpha and has a crucial role in the induction of inflammation. Nat Med 2006, 12:235-239.

50. Nag S, Papneja T, Venugopalan R, Stewart DJ: Increased angiopoietin2 expression is associated with endothelial apoptosis and blood-brain barrier breakdown. Lab Invest 2005, 85(10):1189-1198.

51. Pino P, Taoufiq Z, Nitcheu J, Vouldoukis I, Mazier D: Blood-brain barrier breakdown during cerebral malaria: suicide or murder? Thromb Haemost 2005, 94(2):336-340

52. Conroy AL, Lafferty El, Lovegrove FE, Krudsood S, Tangpukdee N, Liles WC, Kain KC: Whole blood angiopoietin-1 and -2 levels discriminate cerebral and severe (non-cerebral) malaria from uncomplicated malaria. Malar J 2009, 8:295.

53. Lovegrove FE, Tangpukdee N, Opoka RO, Lafferty El, Rajwans N, Hawkes M, Krudsood S, Looareesuwan S, John CC, Liles WC, Kain KC: Serum angiopoietin-1 and -2 levels discriminate cerebral malaria from uncomplicated malaria and predict clinical outcome in African children. PLoS One 2009, 4:e4912.

54. Jain V, Lucchi NW, Wilson NO, Blackstock AJ, Nagpal AC, Joel PK, Singh MP, Udhayakumar V, Stiles JK, Singh N: Plasma levels of angiopoietin-1 and -2 predict cerebral malaria outcome in Central India. Malar J 2011, 10:383.

55. Alam T, An MR, Papaconstantinou J: Differential expression of three C/EBP isoforms in multiple tissues during the acute phase response. $\mathrm{J} \mathrm{Biol} \mathrm{Chem}$ 1992, 267:5021-5024.

56. Baumann H, Morella KK, Campos SP, Cao Z, Jahreis GP: Role of CAAT-enhancer binding protein isoforms in the cytokine regulation of acute-phase plasma protein genes. J Biol Chem 1992, 267:19744-19751.

57. Poli V: The role of C/EBP isoforms in the control of inflammatory and native immunity functions. J Biol Chem 1998, 273:29279-29282.

58. Fields J, Ghorpade A: C/EBPbeta regulates multiple IL-1beta-induced human astrocyte inflammatory genes. J Neuroinflammation 2012, 9:177.

59. Natsuka S, Akira S, Nishio Y, Hashimoto S, Sugita T, Isshiki H, Kishimoto T: Macrophage differentiation-specific expression of NF-IL6, a transcription factor for interleukin-6. Blood 1992, 79:460-466.

60. Kovacs KA, Steinmann M, Magistretti PJ, Halfon O, Cardinaux JR: C/EBPbeta couples dopamine signalling to substance $\mathrm{P}$ precursor gene expression in striatal neurones. J Neurochem 2006, 98:1390-1399.

61. Greenwel P, Tanaka S, Penkov D, Zhang W, Olive M, Moll J, Vinson C, Di Liberto M, Ramirez F: Tumor necrosis factor alpha inhibits type I collagen synthesis through repressive CCAAT/enhancer-binding proteins. Mol Cell Biol 2000, 20:912-918.

62. Maggi CA: The effects of tachykinins on inflammatory and immune cells. Regul Pept 1997, 70:75-90.

63. Armah H, Wired EK, Dodoo AK, Adjei AA, Tettey Y, Gyasi R: Cytokines and adhesion molecules expression in the brain in human cerebral malaria. Int J Environ Res Public Health 2005, 2:123-131.

64. Turner GD, Morrison H, Jones M, Davis TM, Looareesuwan S, Buley ID, Gatter KC, Newbold Cl, Pukritayakamee S, Nagachinta B, White NJ, Berendt AR: An immunohistochemical study of the pathology of fatal malaria. Evidence for widespread endothelial activation and a potential role for intercellular adhesion molecule-1 in cerebral sequestration. Am J Pathol 1994, 145:1057-1069.

65. De Kossodo S, Grau GE: Role of cytokines and adhesion molecules in malaria immunopathology. Stem Cells 1993, 11:41-48.

66. De Vries HE, Blom-Roosemalen MC, Van Oosten M, De Boer AG, Van Berkel TJ, Breimer DD, Kuiper J: The influence of cytokines on the integrity of the blood-brain barrier in vitro. J Neuroimmunol 1996, 64:37-43.

67. Jakobsen PH, McKay V, Morris-Jones SD, McGuire W, Van Hensbroek MB, Meisner S, Bendtzen K, Schousboe I, Bygbjerg IC, Greenwood BM: Increased concentrations of interleukin- 6 and interleukin- 1 receptor antagonist and decreased concentrations of beta-2-glycoprotein I in Gambian children with cerebral malaria. Infect Immun 1994, 62:4374-4379.

68. Kwiatkowski D, Hill AV, Sambou I, Twumasi P, Castracane J, Manogue KR, Cerami A, Brewster DR, Greenwood BM: TNF concentration in fatal cerebral, non-fatal cerebral, and uncomplicated Plasmodium falciparum malaria. Lancet 1990, 336:1201-1204.

69. Lyke KE, Burges R, Cissoko Y, Sangare L, Dao M, Diarra I, Kone A, Harley R, Plowe CV, Doumbo OK, Sztein MB: Serum levels of the proinflammatory cytokines interleukin-1 beta (IL-1beta), IL-6, IL-8, IL-10, tumor necrosis factor alpha, and IL-12(p70) in Malian children with severe Plasmodium falciparum malaria and matched uncomplicated malaria or healthy controls. Infect Immun 2004, 72:5630-5637.

70. Netea MG, Kullberg BJ, Van der Meer JW: Circulating cytokines as mediators of fever. Clin Infect Dis 2000, 31(Suppl 5):S178-S184.

71. Thornton P, McColl BW, Greenhalgh A, Denes A, Allan SM, Rothwell NJ: Platelet interleukin-1alpha drives cerebrovascular inflammation. Blood 2010, 115:3632-3639.

72. Armah HB, Wilson NO, Sarfo BY, Powell MD, Bond VC, Anderson W, Adjei AA, Gyasi RK, Tettey Y, Wiredu EK, Tongren JE, Udhayakumar V, Stiles JK: Cerebrospinal fluid and serum biomarkers of cerebral malaria mortality in Ghanaian children. Malar J 2007, 6:147.

73. Jain V, Armah HB, Tongren JE, Ned RM, Wilson NO, Crawford S, Joel PK Singh MP, Nagpal AC, Dash AP, Udhayakumar V, Singh N, Stiles JK: Plasma IP-10, apoptotic and angiogenic factors associated with fatal cerebral malaria in India. Malar J 2008, 7:83.

74. Wilson NO, Jain V, Roberts CE, Lucchi N, Joel PK, Singh MP, Nagpal AC, Dash AP, Udhayakumar V, Singh N, Stiles JK: CXCL4 and CXCL10 predict risk of fatal cerebral malaria. Dis Markers 2011, 30:39-49.

75. Campanella GS, Tager AM, El Khoury JK, Thomas SY, Abrazinski TA, Manice LA, Colvin RA, Luster AD: Chemokine receptor CXCR3 and its ligands CXCL9 and CXCL10 are required for the development of murine cerebral malaria. Proc Natl Acad Sci USA 2008, 105:4814-4819.

76. Manjurano A, Clark TG, Nadjm B, Mtove G, Wangai H, Sepulveda N, Campino SG, Maxwell C, Olomi R, Rockett KR, Jeffreys A, MalariaGen Consortium, Riley EM, Reyburn H, Drakeley C: Candidate human genetic polymorphisms and severe malaria in a Tanzanian population. PLoS One 2012, 7:e47463.

77. Naka I, Nishida N, Patarapotikul J, Nuchnoi P, Tokunaga K, Hananantachai H, Tsuchiya N, Ohashi J: Identification of a haplotype block in the 5q31 cytokine gene cluster associated with the susceptibility to severe malaria. Malar J 2009, 8:232.

78. Ohashi J, Naka I, Patarapotikul J, Hananantachai H, Looareesuwan S, Tokunaga K: A single-nucleotide substitution from C to $\mathrm{T}$ at position -1055 in the IL-13 promoter is associated with protection from severe malaria in Thailand. Genes Immun 2003, 4:528-531.

79. Prakash D, Fesel C, Jain R, Cazenave PA, Mishra GC, Pied S: Clusters of cytokines determine malaria severity in Plasmodium falciparum-infected patients from endemic areas of Central India. J Infect Dis 2006, 194:198-207.

80. John CC, Park GS, Sam-Agudu N, Opoka RO, Boivin MJ: Elevated serum levels of IL-1ra in children with Plasmodium falciparum malaria are associated with increased severity of disease. Cytokine 2008, 41:204-208.

81. Pasvol G: The treatment of complicated and severe malaria. Br Med Bull 2005, 75-76:29-47.

82. World Health Organization: Guidelines for the treatment of malaria, second edition. http://whqlibdoc.who.int/publications/2010/ 9789241547925_eng.pdf.

83. Aikawa M, Iseki M, Barnwell JW, Taylor D, Oo MM, Howard RJ: The pathology of human cerebral malaria. Am J Trop Med Hyg 1990, 43(2 Pt 2):30-37.

84. Angulo I, Fresno M: Cytokines in the pathogenesis of and protection against malaria. Clin Diagn Lab Immunol 2002, 9:1145-1152.

85. Idro R, Jenkins NE, Newton CR: Pathogenesis, clinical features, and neurological outcome of cerebral malaria. Lancet Neurol 2005, 4:827-840.

86. Hearn J, Rayment N, Landon DN, Katz DR, De Souza JB: Immunopathology of cerebral malaria: morphological evidence of parasite sequestration in murine brain microvasculature. Infect Immun 2000, 68:5364-5376.

87. Baptista FG, Pamplona A, Pena AC, Mota MM, Pied S, Vigario AM: Accumulation of Plasmodium berghei-infected red blood cells in the brain is crucial for the development of cerebral malaria in mice. Infect Immun 2010, 78:4033-4039.

88. Castell JV, Gomez-Lechon MJ, David M, Andus T, Geiger T, Trullenque R, Fabra R, Heinrich PC: Interleukin-6 is the major regulator of acute phase protein synthesis in adult human hepatocytes. FEBS Lett 1989, 242:237-239. 
89. Heinrich $P C$, Castell JV, Andus T: Interleukin- 6 and the acute phase response. Biochem J 1990, 265:621-636.

90. Campbell IL, Abraham CR, Masliah E, Kemper P, Inglis JD, Oldstone MB Mucke L: Neurologic disease induced in transgenic mice by cerebral overexpression of interleukin 6. Proc Natl Acad Sci USA 1993, 90:10061-10065.

91. Issekutz AC, Issekutz TB: Quantitation and kinetics of blood monocyte migration to acute inflammatory reactions, and IL-1 alpha, tumor necrosis factor-alpha, and IFN-gamma. J Immunol 1993, 151:2105-2115.

92. Issekutz AC, Lopes N, Issekutz TB: Role of interleukin-1 and tumour necrosis factor in leukocyte recruitment to acute dermal inflammation. Mediators Inflamm 1992, 1:347-353.

93. Miu J, Mitchell AJ, Muller M, Carter SL, Manders PM, McQuillan JA, Saunders BM, Ball HJ, Lu B, Campbell IL, Hunt NH: Chemokine gene expression during fatal murine cerebral malaria and protection due to CXCR3 deficiency. J Immuno/ 2008, 180:1217-1230.

94. Minhas N, Xue M, Fukudome $\mathrm{K}$, Jackson CJ: Activated protein C utilizes the angiopoietin/Tie2 axis to promote endothelial barrier function. Faseb J 2010, 24:873-881.

95. Fagiani E, Christofori G: Angiopoietins in angiogenesis. Cancer Lett 2013, 328:18-26.

96. Tsigkos S, Koutsilieris M, Papapetropoulos A: Angiopoietins in angiogenesis and beyond. Expert Opin Investig Drugs 2003, 12:933-941.

97. Jeansson M, Gawlik A, Anderson G, Li C, Kerjaschki D, Henkelman M, Quaggin SE: Angiopoietin-1 is essential in mouse vasculature during development and in response to injury. J Clin Invest 2011, 121:2278-2289.

98. Gamble JR, Drew J, Trezise L, Underwood A, Parsons M, Kasminkas L, Rudge J, Yancopoulos G, Vadas MA: Angiopoietin-1 is an antipermeability and anti-inflammatory agent in vitro and targets cell junctions. Circ Res 2000, 87:603-607.

99. Gavard J, Patel V, Gutkind JS: Angiopoietin-1 prevents VEGF-induced endothelial permeability by sequestering Src through mDia. Dev Cell 2008, 14:25-36.

100. Pizurki L, Zhou Z, Glynos K, Roussos C, Papapetropoulos A: Angiopoietin-1 inhibits endothelial permeability, neutrophil adherence and IL-8 production. Br J Pharmacol 2003, 139:329-336.

101. Jho D, Mehta D, Ahmmed G, Gao XP, Tiruppathi C, Broman M, Malik AB: Angiopoietin-1 opposes VEGF-induced increase in endothelial permeability by inhibiting TRPC1-dependent Ca2 influx. Circ Res 2005, 96:1282-1290.

102. Jones N, Iljin K, Dumont DJ, Alitalo K: Tie receptors: new modulators of angiogenic and lymphangiogenic responses. Nat Rev Mol Cell Biol 2001, 2:257-267.

103. Suri $C$, Jones PF, Patan S, Bartunkova S, Maisonpierre PC, Davis S, Sato TN, Yancopoulos GD: Requisite role of angiopoietin-1, a ligand for the TIE2 receptor, during embryonic angiogenesis. Cell 1996, 87:1171-1180.

104. Thurston G, Rudge JS, loffe E, Zhou H, Ross L, Croll SD, Glazer N, Holash J, McDonald DM, Yancopoulos GD: Angiopoietin-1 protects the adult vasculature against plasma leakage. Nat Med 2000, 6:460-463.

105. Uemura A, Ogawa M, Hirashima M, Fujiwara T, Koyama S, Takagi H, Honda Y, Wiegand SJ, Yancopoulos GD, Nishikawa S: Recombinant angiopoietin-1 restores higher-order architecture of growing blood vessels in mice in the absence of mural cells. J Clin Invest 2002, 110:1619-1628.

106. Kim I, Moon SO, Park SK, Chae SW, Koh GY: Angiopoietin-1 reduces VEGF-stimulated leukocyte adhesion to endothelial cells by reducing ICAM-1, VCAM-1, and E-selectin expression. Circ Res 2001, 89:477-479.

107. Mandriota SJ, Pepper MS: Regulation of angiopoietin-2 mRNA levels in bovine microvascular endothelial cells by cytokines and hypoxia. Circ Res 1998, 83:852-859.

108. Roviezzo F, Tsigkos S, Kotanidou A, Bucci M, Brancaleone V, Cirino G, Papapetropoulos A: Angiopoietin-2 causes inflammation in vivo by promoting vascular leakage. J Pharmacol Exp Ther 2005, 314:738-744.

109. Maisonpierre PC, Suri C, Jones PF, Bartunkova S, Wiegand SJ, Radziejewski C, Compton D, McClain J, Aldrich TH, Papadopoulos N, Daly TJ, Davis S, Sato TN, Yancopoulos GD: Angiopoietin-2, a natural antagonist for Tie2 that disrupts in vivo angiogenesis. Science 1997, 277:55-60.

110. Lobov IB, Brooks PC, Lang RA: Angiopoietin-2 displays VEGF-dependent modulation of capillary structure and endothelial cell survival in vivo. Proc Natl Acad Sci USA 2002, 99:11205-11210.

111. Cao Y, Sonveaux P, Liu S, Zhao Y, Mi J, Clary BM, Li CY, Kontos CD, Dewhirst MW: Systemic overexpression of angiopoietin-2 promotes tumor microvessel regression and inhibits angiogenesis and tumor growth. Cancer Res 2007, 67:3835-3844.

112. Mandriota SJ, Pyke C, Di Sanza C, Quinodoz P, Pittet B, Pepper MS: Hypoxia-inducible angiopoietin-2 expression is mimicked by iodonium compounds and occurs in the rat brain and skin in response to systemic hypoxia and tissue ischemia. Am J Pathol 2000, 156:2077-2089.

113. Oh H, Takagi H, Suzuma K, Otani A, Matsumura M, Honda Y: Hypoxia and vascular endothelial growth factor selectively up-regulate angiopoietin-2 in bovine microvascular endothelial cells. J Biol Chem 1999, 274:15732-15739.

114. Takagi H, Koyama S, Seike H, Oh H, Otani A, Matsumura M, Honda Y: Potential role of the angiopoietin/tie2 system in ischemia-induced retinal neovascularization. Invest Ophthalmol Vis Sci 2003, 44:393-402.

115. Nakaoka Y, Nishida K, Narimatsu M, Kamiya A, Minami T, Sawa H, Okawa K, Fujio Y, Koyama T, Maeda M, Sone M, Yamasaki S, Arai Y, Koh GY, Kodama T, Hirota H, Otsu K, Hirano T, Mochizuki N: Gab family proteins are essential for postnatal maintenance of cardiac function via neuregulin-1/ErbB signaling. J Clin Invest 2007, 117:1771-1781.

116. Korff T, Ernst E, Nobiling R, Feldner A, Reiss Y, Plate KH, Fiedler U, Augustin HG, Hecker M: Angiopoietin-1 mediates inhibition of hypertension-induced release of angiopoietin- 2 from endothelial cells. Cardiovasc Res 2012, 94:510-518.

117. Adams S, Brown H, Turner G: Breaking down the blood-brain barrier: signaling a path to cerebral malaria? Trends Parasitol 2002, 18:360-366.

118. Turner G: Cerebral malaria. Brain Pathol 1997, 7:569-582.

119. Erdman LK, Dhabangi A, Musoke C, Conroy AL, Hawkes M, Higgins S, Rajwans N, Wolofsky KT, Streiner DL, Liles WC, Cserti-Gazdewich CM, Kain $\mathrm{KC}$ : Combinations of host biomarkers predict mortality among Ugandan children with severe malaria: a retrospective case-control study. PLoS One 2011, 6:e17440

120. Jenkins N, Wu Y, Chakravorty S, Kai O, Marsh K, Craig A: Plasmodium falciparum intercellular adhesion molecule-1-based cytoadherence-related signaling in human endothelial cells. J Infect Dis 2007, 196:321-327.

121. Turner GD, Ly VC, Nguyen TH, Tran TH, Nguyen HP, Bethell D, Wyllie $S$, Louwrier K, Fox SB, Gatter KC, Day NP, Tran TH, White NJ, Berendt AR: Systemic endothelial activation occurs in both mild and severe malaria. Correlating dermal microvascular endothelial cell phenotype and soluble cell adhesion molecules with disease severity. Am J Pathol 1998 152:1477-1487.

122. Porta J, Carota A, Pizzolato GP, Wildi E, Widmer MC, Margairaz C, Grau GE: Immunopathological changes in human cerebral malaria. Clin Neuropathol 1993, 12:142-146.

123. Grau GE, Pointaire P, Piguet PF, Vesin C, Rosen H, Stamenkovic I, Takei F, Vassalli P: Late administration of monoclonal antibody to leukocyte function-antigen 1 abrogates incipient murine cerebral malaria. Eur J Immunol 1991, 21:2265-2267

124. Grau GE, Tacchini-Cottier F, Vesin C, Milon G, Lou JN, Piguet PF, Juillard P: TNF-induced microvascular pathology: active role for platelets and importance of the LFA-1/ICAM-1 interaction. Eur Cytokine Netw 1993 4:415-419.

125. Lucas R, Lou JN, Juillard P, Moore M, Bluethmann H, Grau GE: Respective role of TNF receptors in the development of experimental cerebral malaria. J Neuroimmunol 1997, 72:143-148.

126. Kim I: Vascular Endothelial Growth Factor Expression of Intercellular Adhesion Molecule 1(ICAM-1), Vascular Cell Adhesion Molecule 1 (VCAM-1) and E-Selectin through Nuclear Factor - $\mathrm{KB}$ Activation in Endothelial Cells. J Biol Chem 2001, 276:7614-7620.

127. Conroy AL, Phiri H, Hawkes M, Glover S, Mallewa M, Seydel KB, Taylor TE, Molyneux ME, Kain KC: Endothelium-based biomarkers are associated with cerebral malaria in Malawian children: a retrospective case-control study. PLoS One 2010, 5:e15291

128. Li J, Chang WL, Sun G, Chen HL, Specian RD, Berney SM, Kimpel D, Granger DN, Van der Heyde HC: Intercellular adhesion molecule 1 is important for the development of severe experimental malaria but is not required for leukocyte adhesion in the brain. J Investig Med 2003, 51:128-140.

129. Sun G, Chang WL, Li J, Berney SM, Kimpel D, Van der Heyde HC: Inhibition of platelet adherence to brain microvasculature protects against severe Plasmodium berghei malaria. Infect Immun 2003, 71:6553-6561.

130. Guo WP, Fu XG, Jiang SM, Wu JZ: Neuregulin-1 regulates the expression of Akt, $\mathrm{Bcl}-2$, and Bad signaling after focal cerebral ischemia in rats. Biochem Cell Biol 2010, 88:649-654. 
131. Xiao J, Li B, Zheng Z, Wang M, Peng J, Li Y, Li Z: Therapeutic effects of neuregulin-1 gene transduction in rats with myocardial infarction. Coron Artery Dis 2012, 23:460-468.

132. Gao R, Zhang J, Cheng L, Wu X, Dong W, Yang X, Li T, Liu X, Xu Y, Li X, Zhou M: A Phase II, randomized, double-blind, multicenter, based on standard therapy, placebo-controlled study of the efficacy and safety of recombinant human neuregulin-1 in patients with chronic heart failure. J Am Coll Cardiol 2010, 55:1907-1914.

133. Jabbour A, Hayward CS, Keogh AM, Kotlyar E, McCrohon JA, England JF, Amor R, Liu X, Li XY, Zhou MD, Graham RM, Macdonald PS: Parenteral administration of recombinant human neuregulin-1 to patients with stable chronic heart failure produces favourable acute and chronic haemodynamic responses. Eur J Heart Fail 2011, 13:83-92.

134. Xu Y, Li X, Liu X, Zhou M: Neuregulin-1/ErbB signaling and chronic heart failure. Adv Pharmacol 2010, 59:31-51.

135. Guo WP, Wang J, Li RX, Peng YW: Neuroprotective effects of neuregulin-1 in rat models of focal cerebral ischemia. Brain Res 2006, 1087:180-185.

136. Shyu WC, Lin SZ, Chiang MF, Yang HI, Thajeb P, Li H: Neuregulin-1 reduces ischemia-induced brain damage in rats. Neurobiol Aging 2004, 25:935-944.

doi:10.1186/1742-2094-11-9

Cite this article as: Solomon et al: Neuregulin-1 attenuates mortality associated with experimental cerebral malaria. Journal of

Neuroinflammation 2014 11:9.

\section{Submit your next manuscript to BioMed Central and take full advantage of:}

- Convenient online submission

- Thorough peer review

- No space constraints or color figure charges

- Immediate publication on acceptance

- Inclusion in PubMed, CAS, Scopus and Google Scholar

- Research which is freely available for redistribution 